\title{
GAMBARAN UPAYA IBU DALAM PEMENUHAN KONSUMSI SAYUR DAN BUAH PADA ANAK PRASEKOLAH
}

\author{
Riauni Syaputri, Yecy Anggreny, Sekani Niriyah \\ Fakultas Program Studi Keperawatan STIKes Hangtuah Pekanbaru \\ ${ }^{*}$ Correspondence: rsyaputri97@gmail.com \\ Dikirim 07 Juli 2019; Diterima o9 Juli 2019; Dipublikasi Agustus 2019
}

\begin{abstract}
The period of growth and development in preschoolers is strongly influenced by the provision of nutrition and food intake, but mothers can not always to fulfil these needs, especially in fulfilling the consumption of vegetables and fruit. This study aims to determine the description of maternal efforts in fulfilling the consumption of vegetables and fruit in preschool children. This research was a quantitative study with a descriptive research design. The study population was all mothers who have preschool children in Public Health Centre "Payung Sekaki Pekanbaru". Total sample 192 people, taken by Proportional Random Sampling technique. The process of collecting data using an instrument in the form of a questionnaire. Data was analized by the Chi-square test. The results showed that of the 192 respondents most of which are 169 people (88.o\%) have adequate eating habits, parenting eating most obtained good parenting patterns that are 191 people (99.5\%), feeding practices of most respondents were correct namely 97 people (50.5\%), the majority of respondents provide good food namely 190 people (99.0\%), and the method of food processing shows that the majority of respondents have processed food properly, namely 145 people (75.5\%). Mother's efforts in fulfilling the consumption of vegetables and fruit in preschool children in the work area of Payung Sekaki Health Center are good. It is expected that the public health centre will always provide counselling to the public on the importance of balanced food consumption, one of which is to consume spinach and spinach as well as papaya and bananas which have many benefits for children's growth and development, as well as educating parents to more routinely provide vegetable and fruit intake in children every meal hour.
\end{abstract}

Keywords: Food intake, Vegetable and fruit Consumption, Preschool, Mother's Efforts

\section{PENDAHULUAN}

Ilmu gizi adalah pengetahuan yang mengajarkan bagaimana tentang bagian dari makanan berserta bagiannya yang mempengaruhi kesehatan dan daya tubuh seorang manusia. Manusia sangat membutuhkan berbagai macam jenis zat gizi yang dibutuhkan tubuh untuk menghasilkan energi dan mampu memelihara jaringan tubuh. Zat gizi yang dibutuhkan oleh tubuh terdiri dari protein, karbohidrat, vitamin, mineral, dan lemak untuk pertumbuhan dan perkembangan(1).

Pada saat pertumbuhan dan perkembangan, nutrisi atau asupan makanan yang diberikan kepada anak tidaklah selalu sempurna, terkadang juga pernah timbul masalah dalam asupan tersebut, seperti pemenuhan pemberian komsumsi sayur dan buah(2). Masalah yang ditimbulkan dalam pemberian makanan yang tidak benar menyebabkan anak tidak suka mengkonsumsi sayur dan buah. Sayur merupakan sumber zat pengatur, yaitu sumber vitamin dan mineral. Sayuran merupakan salah satu sumber provitamin $\mathrm{A}$, vitamin $\mathrm{C}$, vitamin $\mathrm{B}, \mathrm{Ca}, \mathrm{Fe}$, menyumbang sedikit kalori serta sejumlah elemen mikro. Vitamin dan mineral dibutuhkan oleh tubuh. Kandungan sayur tersebut sangat penting dalam proses tumbuh kembang khususnya pada anak-anak. Sayur dan buah merupakan sumber zat gizi mikro yang sangat bermanfaat bagi tubuh, karena kedua komponen gizi 
tersebut sangat penting dalam proses metabolisme tubuh sebagai zat pengatur, antibodi dan penurunan insiden terkena penyakit pada anak(3).

Dampak yang ditimbulkan dari kurangnya mengkonsumsi sayur dan buah diantaranya adalah terkena penyakit pada anak, terhambatnya tumbuh kembang pada anak dikarenakan tubuh kekurangan asupan, sehingga akan mengalami dampak penyakit seperti gangguan penglihatan, menurunkan kekebalan tubuh, risiko kegemukan, risiko sembelit dan meningkatkan penyakit sariawan, obesitas pada anak usia sekolah. Agar anak terhindar dari risiko penyakit akibat tidak mengkonsumsi sayur dan buah salah satunya dengan pemenuhan nutrisi supaya tumbuh kembang anak tidak terganggu. Masalah yang terjadi dapat berupa gusi menjadi pucat karena kekurangan vitamin $\mathrm{C}$, penurunan tajam penglihatan, kulit kusam, mudah stress, masalah pencernaan, menurunnya sistem imun dan mudah merasa lelah (4).

Bersadarkan penelitian Inggit pada tahun 2012 diperoleh data bahwa kurang minatnya anak terhadap suatu makanan tertentu dan kurang bervariasi seperti jenis makanannya. Hasil dari penelitian didapatkan bahwa jenis makanan yang sering dikonsumsi untuk anak-anak adalah beras, telur, wortel, pisang, tempe dan susu kental manis. Beras dan telur merupakan jenis makanan yang paling dianjurkan, sedangkan sayuran, buah, lauk pauk nabati dan susu menjadi terakir jenis makanan yang dianjurkan untuk dikomsumsi.

Berdasarkan hasil Riset Kesehatan Dasar (Riskesdas) tahun 2013 konsumsi sayur dan buah 93,5\% sejalan dengan Food and Agriculture Organization (FAO) 35 $\mathrm{kg} / \mathrm{kapita} / \mathrm{tahun}$, lebih rendah dari beberapa Negara asia lainnya, dan jauh dibawah rekomendasi FAO yaitu sebanyak 75 kg/kapita/tahun. Hasil Riset Kesehatan Dasar (Riskesdas) tahun 2018 terjadi peningkatan konsumsi sayur dan buah menjadi 98,5\% namun dalam proporsi Perilaku Hidup Bersih dan Sehat (PHBS) nya merupakan indikator terendah yaitu 10,7\% (Riskesdas, 2013).

Pada tahun 2016 didapatkan hasil dari Badan Pusat Statistik dan Survei Sosial Ekonomi Nasional bahwa konsumsi buah dan sayur di Indonesia berada dibawah dari bahan makanan yang kurang dikomsumsi, yaitu sebanyak 173 gram/kapita/hari dari Angka Kecukupan Gizi (AKG) yang direkomendasikan sebesar 400 gram/kapita/hari. Konsumsi buah lebih sedikit daripada konsumsi sayur yaitu 67 gram/kapita/hari sedangkan sayur sebesar 107 gram/kapita/hari. Konsumsi buah-buahan dan sayur di Provinsi Riau 160 gram/kapita/hari belum memenuhi konsumsi yang direkomendasikan yaitu sebanyak 173 gram/kapita/hari. Buah yang direkomendasikan untuk menunjang tumbuh kembang anak yaitu pisang dan papaya serta sayur kangkung dan bayam karena mudah didapat serta harganya terjangkau (BPS,2016).

Hasil survey yang dilakukan peneliti di Wilayah Kerja Puskesmas Payung Sekaki pada hari Selasa 02 April 2019 melalui wawancara terhadap 10 orang ibu yang mempunyai anak pra sekolah didapatkan 7 orang ibu mengatakan bahwa kebiasaan makan pada anak masih buruk, ibu membiarkan anaknya tidak menyukai sayur, ibu hanya menyediakan sayur dan buah sesuai kebutuhan dan ibu mengatakan tidak ada upaya yang dilakukannya untuk anaknya supaya mengkonsumsi sayur . sebanyak 3 orang ibu mengatakan bahwa anaknya memiliki preferensi tertentu mengkonsumsi sayur, seperti Wortel, Kentang dan buah seperti Pepaya. Ibu mengatakan tidak selalu menyediakan sayur dan buah yang disukai anaknya dirumah, ibu hanya menyediakan sayur dan buah sesuai kebutuhan, dan juga tidak ada upaya yang dilakukannya supaya anaknya lebih menyukai sayur.

Berdasarkan latar belakang diatas, ada beberapa permasalahan dalam perilaku konsumsi sayur dan buah pada anak pra sekolah di wilayah Kerja Puskesmas Payung Sekaki Kota Pekanbaru untuk diteliti penyebabnya antara lain bagaimana kebiasaan makan, pola asuh makan, praktik pemberian makan, penyediaan makanan dan cara pengolahan makanan. Untuk itu perlu dilakukan penelitian mengenai "Gambaran Upaya Ibu Dalam Pemenuhan Konsumsi Sayur dan Buah Pada Anak Prasekolah" 


\section{METODE PENELITIAN}

Jenis Penelitian ini merupakan penelitian kuantitatif dengan desain penelitian deskriptif. Populasi penelitian ini yaitu seluruh ibu yang mempunyai anak pra sekolah yang berada di wilayah kerja Puskesmas Payung Sekaki yang berjumlah 192 responden. Jenis teknik sampling yang digunakan pada penelitian ini ialah proportional random sampling. Intstrumen penelitian yang digunakan adalah angket/kuesioner yang diisi dengan cara memberikan tanda centang. Peneliti kemudian melakukan pengolahan data melalui program komputer. Peneliti menganalisis data yang meliputi analisa univariat terkait karakteristik responden, kebiasaan makan, pola asuh makan, praktek pemberian makan, penyediaan makan, dan cara pengolahan makan.

\section{HASIL DAN PEMBAHASAN}

Karakteristik responden dalam penelitian ini dilihat dari tiga aspek yaitu usia ibu, usia anak dan pendidikan ibu, seperti pada tabel 1.

Tabel 1. Karakteristik Responden

\begin{tabular}{cccc}
\hline No & Karakteristik responden & f & $\%$ \\
\hline 1 & Usia Ibu & & \\
& 17-25 tahun (remaja akhir) & 6 & $3,1 \%$ \\
& $26-35$ tahun (dewasa awal) & 111 & $57,8 \%$ \\
& $36-45$ tahun (dewasa akhir) & 73 & $38,0 \%$ \\
& $46-55$ tahun (lansia) & 2 & $1,0 \%$ \\
\hline & & & \\
& Usia Anak & 51 & $26,6 \%$ \\
3 tahun & 39 & $20,3 \%$ \\
4 tahun & 45 & $23,4 \%$ \\
5 tahun & 57 & $29,7 \%$ \\
\hline & 6 tahun & & \\
& Pendidikan Ibu & 1 & $5 \%$ \\
SD & 23 & $12,0 \%$ \\
SMP & 88 & $45,8 \%$ \\
SMA & 78 & $40,6 \%$ \\
S1 & 2 & $1,0 \%$ \\
\hline & S2 & 192 & $100 \%$ \\
\hline
\end{tabular}

Berdasarkan tabel 1 diperoleh informasi bahwa usia ibu di Wilayah Kerja Puskesmas Payung Sekaki berada pada rentang usia remaja akhir (17-25 tahun) yaitu sebanyak 6 orang $(3,1 \%)$, pada rentang usia dewasa awal (26-35 tahun) yaitu sebanyak 111 orang $(57,8 \%)$, sedangkan di rentang usia dewasa akhir (36-45 tahun) yaitu sebanyak 73 orang (38,0\%) dan ibu dengan usia lansia (46-55 tahun) diperoleh sebanyak 2 orang (1,0\%). Karakteristik responden dengan usia anak di Wilayah Kerja Puskesmas Payung Sekaki berada pada rentang usia 3 tahun sebanyak 51 orang (26,6\%), pada usia 4 tahun sebanyak 39 orang (20,3\%), sedangkan pada usia 5 tahun sebanyak 45 orang $(23,4 \%)$ dan pada usia 6 tahun sebanyak 57 orang $(29,7 \%)$.

Berdasarkan hasil penelitian didapatkan hasil bahwa sebagian besar responden ibu pada usia dewasa awal dalam rentang usia 26-35 tahun sebanyak 111 orang (57,8\%). Rentang usia tersebut merupakan kategori dewasa awal. Rentang usia tersebut secara teori menunjukkan ciri khas secara individu akan mempelajari dan menyesuaikan diri pada situasi seperti pada mengingat hal-hal yang pernah dipelajari, penalaran analogis dan berfikir kreatif(5).

Pada usia dewasa awal ibu memainkan peran baru seperti peran sebagai istri, orang tua dan mengembangkan sikap-sikap baru, keinginan-keinginan dan nilai-nilai baru sesuai dengan tugas-tugas baru. Pada usia dewasa awal juga terjadi masa ketegangan emosional yaitu emosi yang bergelora yang merupakan ciri-ciri tahun awal kedewasaan, hal ini merupakan tanda bahwa penyesuaian diri pada kehidupan dewasa belum terlaksana sepenuhnya. Sebagai individu dewasa awal, seorang wanita memainkan peran yang sangat penting dalam pertumbuhan dan 
perkembangan anak. Pada usia tersebut wanita juga harus pandai dalam mengatur waktu untuk dirinya sendiri, keluarganya termasuk dalam menjadwalkan waktu makan pada anak(6). Berdasarkan penelitian ini, peneliti menyimpulkan bahwa pada tahap dewasa awal individu memiliki konsep diri yang stabil dan motivasi yang baik untuk lebih mengembangkan lagi pengetahuannya. Semakin bertambahnya usia tentu terjadi juga peningkatan cara berfikir dan bertindak dalam melakukan suatu pekerjaan sehingga pekerjaan yang dilakukan dapat memberikan hasil yang maksimal termasuk dalam pemenuhan konsumsi sayur dan buah pada anak. Peran ibu dalam keluarga yaitu memperkenalkan beragam jenis makanan kepada anak. Dimulai dari jenis sayuran dan buahan dan menjelaskan betapa pentingnya untuk mengkonsumsi sayuran buahan untuk tumbuh dan kembang pada anak.

Berdasarkan hasil penelitian didapatkan hasil bahwa sebagian besar responden memiliki anak berusia 6 tahun sebanyak 57 orang (29,7\%). Menurut Tejasari pada tahun 2014 menjelaskan bhahwa anak yang berusia 6 tahun menunjukkan masa perkembangan motorik anak yang paling menonjol, karena pada usia tersebut rasa ingin tahu seorang anak dalam terhadap berbagai jenis makanan meningkat. Peran ibu sangat dibutuhkan dalam mengajarkan, mengawasi, dan membimbing anak dalam pemilihan makanan khususnya mengkonsumsi sayur dan buah(7).

Seorang anak yang berusia 3-6 tahun dikenal dengan anak usia prasekolah, pada anak sedang menjalani proses pertumbuhan akan membutuhkan asupan gizi yang relatif besar. Pada tahap ini pengetahuan anak mulai terbentuk melalui proses meniru dengan penginderaan. Proses tumbuh kembang anak sangat membutuhkan nutrisi. Pemenuhan nutrisi memiliki peranan yang sangat penting untuk mendukung mencapai tumbuh kembang anak yang maksimal, Nutrisi didapatkan dari makanan yang dikonsumsi oleh seorang anak termasuk mengkonsumsi sayur dan buah(8).

Pada saat bayi, mereka tidak akan dapat memilih jenis makanan yang akan mereka konsumsi. Tetapi pada saat mereka menginjak masa kanak-kanak, maka mereka akan menunjukkan rasa ketidaksukaan terhadap suatu makanan(9). Pada anak prasekolah yang sering terjadi yaitu kesulitan makan. Hal ini terjadi dikarenakan ada beberapa faktor, yaitu faktor psikologis yang meliputi cara pemberian makan, suasana saat makan dan variasa makanan yang diberikan. Kedua yaitu faktor organic, meliputi penyakit percernaan. Ketiga faktor pengaturan makan yaitu jenis makanan(10).

Berdasarkan penelitian, peneliti menyimpulkan bahwa pada anak usia prasekolah kecukupan untuk mengkonsumsi buah dan sayuran per otangan dalam satu hari membutuhkan asupan nutrisi yang baik dalam mendukung pertumbuhannya, berhubungan dengan faktor penghambat yang sering terjadi pada anak usia prasekolah seperti faktor psikologis sehingga ibu diharuskan mampu dalam melakukan pengaturan makan dan variasi menu makanan bagi anak. peran ibu dalam keluarga sebagai edukator. Hal ini bisa dilihat dari sang ibu mengatur pemilihan makanan, anggaran biaya serta menentukan cara olahan makanan. Pada tabel 3 didaptkan bahwa sebagain besar ibu yang berperan baik sebagai educator memiliki anak dengan tingkat konsumsi sayur dan buah yang kurang yaitu 86,7\%

Mayoritas pendidikan ibu adalah SD sebanyak 1 orang (5\%), pendidikan SMP sebanyak 23 orang $(12,0 \%)$, pendidikan SMA sebanyak 88 orang $(45,8 \%)$, pendidikan S1 sebanyak 78 orang $(40,6)$, dan pendidikan S2 sebanyak 2 orang $(1,0 \%)$. Berdasarkan hasil penelitian yang dilakukan terhadap 192 responden didapatkan bahwa sebagian besar responden memiliki tingkat pendidikan SMA sebanyak 88 orang (45,8\%), S1 sebanyak 78 orang (40,6\%), SMP sebanyak 23 orang (12,0\%), S2 sebanyak 2 orang $(1,0 \%)$ dan SD sebanyak 1 orang (5\%). Penelitian ini sejalan dengan penelitian yang dilakukan Ali \& Enik (2012), mengatakan bahwa tingkat pendidikan ibu lebih banyak dijenjang SMA yaitu 34 orang (54,0\%) dibandingkan dengan yang telah menempuh jenjang S1 yaitu sebanyak 5 orang $(7,9 \%)$.

Salah satu hal penting dalam pemenuhan status gizi pada anak yaitu pendidikan orang tua, karena dari pendidikan orang tua dapat berfikir dan dapat memperoleh informasi tentang cara mendidik anak, memberikan makanan yang bergizi, dan semakin bagus pola asuh orang tua yang baik untuk anaknya(11).

Menurut Ali pada tahun 2016 mengatakan bahwa tingkat jenjang pendidikan yang tinggi dapat memudahkan seseorang untuk mendapatkan informasi dan mempraktekkan dalam perilaku dan gaya hidup sehari-hari, terutama wanita dalam 
pengetahuan tentang gizi yang baik seperti komsumsi sayur dan buah.

Berdasarkan penelitian, peneliti menyimpulkan bahwa pendidikan orang tua juga merupakan peranan sangat penting dalam pemenuhan konsumsi sayuran dan buahan pada anak prasekolah. Tingkat pendidikan akan berpengaruh terhadap memberi respon yang datang dari luar. Orang yang berpendidikan tinggi akan memberi respon yang rasional terhadap informasi yang datang dan berfikir sejauh mana keuntungan yang diperoleh dari informasi tersebut sehingga mampu memenuhi kebutuhan konsumsi sayur dan buah pada anak prasekolah.

Berdasarkan Penelitian Windi tahun 2016 didapatkan hasil bahwa di SDN Sekaran dari 17 responden. Pendidikan tinggi (23,5\%) dengan konsumsinya baik sebanyak 76,5 . Pendidikan rendah $(81,3)$ dengan tingkat konsumsi kurang sebanyak 18,7\%. Sedangkan di SD Negeri Pekunden didapatkan dari 35 responden, pengetahuan gizi yang baik sebanyak $57,1 \%$ atau 20 responden dengan tingkat konsumsi baik sebanyak 42,9\% atau 15 responden dan dari 12 responden yang pendidikan rendah dengan tingkat komsumsi kurang 50\% atau 6 responden dan dapat disimpulkan bahwa responden yang memiliki pendidikan rendah memiliki resiko konsumsi buah dan sayur kurang yaitu 3,5 kali lebih besar dibandingkan responden yang memiliki pendidikan tinggi.

Tabel 2. Kebiasaan Makan, Pola Asuh Makan, Praktik Pemberian Makan, Penyediaan Makan, Cara Pengolahan Makan Konsumsi Sayur dan Buah

\begin{tabular}{|c|c|c|}
\hline Variabel & $\mathbf{F}$ & $\%$ \\
\hline \multicolumn{3}{|l|}{ Kebiasaan Makan } \\
\hline a. Lebih & 0 & $\mathrm{O}$ \\
\hline b. Cukup & 169 & 88,0 \\
\hline c. Kurang & 23 & 12,0 \\
\hline Total & 192 & 100 \\
\hline \multicolumn{3}{|l|}{ Pola Asuh Makan } \\
\hline a. Baik & 191 & 99,5 \\
\hline b. Cukup baik & 1 & 5 \\
\hline c. Tidak baik & O & O \\
\hline Total & 192 & 100 \\
\hline \multicolumn{3}{|l|}{ Praktek Pemberian } \\
\hline Makan & 97 & 50,5 \\
\hline $\begin{array}{l}\text { a. Benar } \\
\text { b. Salah }\end{array}$ & 95 & 49,5 \\
\hline Total & 192 & 100 \\
\hline \multicolumn{3}{|l|}{ Penyediaan Makan } \\
\hline a. Baik & 190 & 99,0 \\
\hline b. Cukup baik & 2 & 1,0 \\
\hline c. Tidak baik & $\mathrm{O}$ & 0 \\
\hline Total & 192 & 100 \\
\hline \multicolumn{3}{|l|}{ Cara Pengolahan } \\
\hline Makan & 145 & 75,5 \\
\hline $\begin{array}{l}\text { a. Benar } \\
\text { b. Salah }\end{array}$ & 47 & 24,5 \\
\hline Total & 192 & 100 \\
\hline
\end{tabular}

Berdasarkan tabel 2 dapat dilihat dari 192 responden pada penelitian ini didapatkan sebagian besar kebiasaan makan cukup yaitu 169 orang (88,0\%), selain itu untuk pola asuh makan didapatkan hasil sebagian besar pola asuh makan baik yaitu sebanyak 191 orang (99,5\%), untuk praktik pemberian makan sebagian besar responden benar yaitu sebanyak 97 orang (50,5\%), untuk penyediaan makan sebagian besar responden baik yaitu sebanyak 190 orang (99,0\%), dan untuk cara pengolahan makan sebagian besar benar yaitu 145 orang (75,5\%). Sebagian besar responden $>3$ kali frekuensi pemberian makan anak dalam 1 hari sebanyak 139 orang (72,4\%), 1 kali frekuensi makan sayur dalam 1 hari sebanyak 132 orang $(68,8 \%), 1$ kali frekuensi makan buah dalam 1 hari sebanyak 109 orang (56,8\%).

Kebiasaan makan yang dimiliki seseorang atau sekelompok manusia untuk memenuhi kebutuhan hidupnya meliputi dari sikap positif dan negatif, dan 
kepercayaan dalam pemilihan makanan yang akan dipilih untuk dikonsumsi(12).

Kebiasaan makan berkaitan dengan konsumsi makanan yang mencakup jumlah makanan, frekuensi seringnya mengkonsumsi makanan dan cara memilih jenis makanan yang dapat diperoleh dan dipengaruhi beberapa faktor social dan budaya disekitar lingkungan(13). Penelitian ini sejalan dengan penelitian yang dilakukan Rona pada tahun 2017, mengatakan bahwa kebiasaan makan pada anak dalam konsumsi sayur dan buah dibutuhkan peran serta banyak pihak selain orang tua. Orang tua diharapkan secara rutin memberikan motivasi anak agar mengkonsumsi sayur dan buah, termasuk mengenalkan jenis, manfaat, kandungan serta akibat kurang mengkonsumsi sayur dan buah(14).

Berdasarkan penelitian, peneliti menyimpulkan bahwa kebiasaan makan pada anak di Wilayah Kerja Puskesmas Payung Sekaki ini dalam kategori baik, dimana hampir semua pertanyaan dengan jawaban yang positif sebanyak $(72,4 \%)$. Jumlah, frekuensi makanan dikeluarga juga sudah baik. Ibu juga harus menyediakan makanan yang bervariasi dan menu yang berbeda-beda setiap harinya supaya anak tidak bosan dengan menu masakan yang disajikan, frekuensi makanan yang ketat seperti anak disuruh makan sesuai dengan waktu yang ditentukan akan menyebabkan anak menjadi tertekan dan stress sehingga kehilangan nafsu makan, maka akibatnya anak menjadi sulit makan atau malas makan. Pada anak, kebiasaan makan dilihat dari peran ibu yang memberikan komsumsi buahan dan sayuran, jika sang ibu mengatur dan membiasakan memberikan menu seimbang setiap harinya, maka secara tidak langsung ibu membentuk kebiasaan makan yang baik.

Berdasarkan penelitian putri (2017) mengatakan bahwa jenis makanan yang banyak disediain lebih banyak peluang untuk dikomsumsi daripada jenis makanan yang kurang tersedia akan kurang dikomsumsi (16). Penelitian ini didapatkan bahwa ibu yang menyediakan sayuran dan buahan sebesar 73,2\%, dan ibu yang kurang menyediakan sayuran dan buahan sebear $82,4 \%$ dengan nilai p-value 0,003 , artinya bahwa ada pengaruh antara ketersediaan sayur dan buah di rumah terhadap konsumsi sayur dan buah pada anak.

Tabel 3. Identifikasi Kebiasaan makan dalam Pemenuhan Konsumsi Sayur dan Buah

\begin{tabular}{lcccccc}
\hline \multicolumn{1}{c}{ Kebiasaan Makan } & \multicolumn{2}{c}{ 1 kali } & \multicolumn{2}{c}{ 2 kali } & \multicolumn{2}{c}{$>$ kali } \\
\cline { 2 - 7 } & $\mathrm{N}$ & $\%$ & $\mathrm{~N}$ & $\%$ & $\mathrm{~N}$ & $\%$ \\
\hline $\begin{array}{l}\text { Frekuensi Makan Anak } \\
\text { dalam 1 hari }\end{array}$ & 2 & 1.0 & 51 & 26.6 & 139 & 72.4 \\
\hline $\begin{array}{l}\text { Frekuensi makan sayur } \\
\text { dalam 1 hari }\end{array}$ & 132 & 68.8 & 49 & 25.5 & 11 & 5.7 \\
\hline $\begin{array}{l}\text { Frekuensi makan buah } \\
\text { dalam 1 hari }\end{array}$ & 109 & 56.8 & 71 & 37.0 & 12 & 6.3 \\
\hline
\end{tabular}

Berdasarkan tabel 3 diatas dapat dilihat dari 192 responden pada penelitian ini didapatkan sebagian besar responden $>3$ kali frekuensi makan anak dalam 1 hari sebanyak 139 orang $(72,4 \%), 1$ kali frekuensi makan sayur dalam 1 hari sebanyak 132 orang $(68,8 \%)$, 1 kali frekuensi makan buah dalam 1 hari sebanyak 109 orang $(56,8 \%)$. 


\begin{tabular}{|c|c|c|c|c|c|c|}
\hline \multirow[t]{2}{*}{ Pola Asuh Makan } & \multicolumn{2}{|c|}{ Selalu } & \multicolumn{2}{|c|}{$\begin{array}{l}\text { Kadang- } \\
\text { Kadang }\end{array}$} & \multicolumn{2}{|c|}{ Tidak Pernah } \\
\hline & $\mathrm{N}$ & $\%$ & $\mathrm{~N}$ & $\%$ & $\mathrm{~N}$ & $\%$ \\
\hline $\begin{array}{l}\text { Komunikasi untuk } \\
\text { menghabiskan makan }\end{array}$ & 78 & 92.7 & 12 & 6.3 & 2 & 1.0 \\
\hline $\begin{array}{l}\text { Memberitahu hal yang } \\
\text { positif tentang sayur } \\
\text { dan buah }\end{array}$ & 171 & 89.1 & 18 & 9.4 & 3 & 1.6 \\
\hline $\begin{array}{l}\text { Menata sayur dan buah } \\
\text { lebih menarik }\end{array}$ & 101 & 53.6 & 66 & 34.4 & 25 & 13.0 \\
\hline $\begin{array}{l}\text { Memberikan makanan } \\
\text { tambahan setelah } \\
\text { selesai makan }\end{array}$ & 102 & 53.1 & 64 & $33 \cdot 3$ & 26 & $13 \cdot 5$ \\
\hline $\begin{array}{l}\text { Menawarkan } \\
\text { tambahan porsi } \\
\text { makanan }\end{array}$ & 81 & 42.2 & 72 & 37.5 & 39 & 20.3 \\
\hline $\begin{array}{l}\text { Mengajak anak } \\
\text { mencoba varian } \\
\text { sayuran baru }\end{array}$ & 119 & 62.0 & 63 & 32.8 & 10 & 5.2 \\
\hline $\begin{array}{l}\text { Memaksa anak untuk } \\
\text { makan apa yang } \\
\text { dimasak }\end{array}$ & 102 & 53.1 & 62 & 32.3 & 28 & 14.6 \\
\hline $\begin{array}{l}\text { Marah jika anak tidak } \\
\text { menghabiskan makan }\end{array}$ & 120 & 62.4 & 36 & 18.8 & 36 & 18.8 \\
\hline $\begin{array}{l}\text { Menghias sayur dan } \\
\text { buah yang menarik }\end{array}$ & 70 & 36.5 & 84 & 43.8 & 38 & 19.8 \\
\hline $\begin{array}{l}\text { Komposisi makanan } \\
\text { dengan warna yang } \\
\text { sama }\end{array}$ & 162 & 84.4 & 19 & 9.9 & 11 & $5 \cdot 7$ \\
\hline $\begin{array}{l}\text { Memberikan porsi } \\
\text { makan anak dengan } \\
\text { banyak }\end{array}$ & 171 & 89.1 & 14 & $7 \cdot 3$ & 7 & 3.6 \\
\hline
\end{tabular}

Hasil penelitian didapatkan bahwa dari 192 responden didapatkan sebagian besar responden baik Komunikasi untuk menghabiskan makan sebanyak 78 orang (92,7\%), untuk Memberitahu hal yang positif tentang sayur dan buah sebagian besar baik sebanyak 171 orang (89,1\%), sebagian besar baik Menata sayur dan buah lebih menarik sebanyak 101 orang (53,6\%), sebagian besar baik Memberikan makanan tambahan setelah selesai makan sebanyak 102 orang (53,1\%), sebagian besar baik menawarkan tambahan porsi makanan sebanyak 81 orang $(42,2 \%)$, sebagian besar baik mengajak anak mencoba varian sayuran baru sebanyak 119 orang (62,0\%), sebagian besar baik memaksa anak untuk makan apa yang dimasak sebanyak 102 orang (53.1), sebagian besar baik jika anak tidak menghabiskan makan sebanyak 120 orang (62.4\%), sebagian besar kadang-kadang menghias sayur dan buah yang menarik sebanyak 84 orang (43.8), sebagian besar baik momposisi makanan dengan warna yang sama sebanyak 162 orang (84.4\%), sebagian besar baik memberikan porsi makan anak dengan banyak sebanyak 171 orang (89.1\%).

Penelitian ini sejalan dengan penelitian Hermina (2016), bahwa pola asuh makan merupakan perilaku yang sangat untuk memilih kuantitas dan kualitas makanan dan minuman yang dikonsumsi karena akan berpengaruh terhadap asupan zat-zat gizi sehingga akan mempengaruhi kesehatan individu tersebut.

Pada usia anak prasekolah ketika anak memasuki usia tersebut anak mulai mendapat pengaruh dari lingkungan luar seperti guru, teman sebaya dan pengaruh dari media social. Pola asuh makan yang dilakukan orang tua tidak menjamin membentuk preferensi anak terhadap makanan sehat dan bergizi. Kualitas pola asuh makan juga harus diterapkan ibu dirumah supaya pemenuhan konsumsi sayur dan buah pada anak terpenuhi dengan baik (15). 
pengaruh tingkat pendidikan pada pola asuh makan dan kebiasaan makan anak menyebutkan bahwa terdapat perbedaan pada pola asuh makan di antara ibu yang memiliki tingkat pendidikan yang berbeda. Ibu dengan tingkat pendidikan tinggi lebih tidak permisif mengenai kebiasaan makan anaknya, lebih sering memuji anaknya ketika anak mengonsumsi sayur dan buah, dan lebih sering menghindari makanan manis saat di depan anaknya dibandingkan ibu dengan tingkat pendidikan rendah (lulus SD atau SMP). Ibu dengan tingkat pendidikan tinggi dan menengah (lulus SMA) lebih sering bernegosiasi dengan anaknya dibandingkan ibu dengan tingkat pendidikan rendah(16).

Hasil penelitian dari Dwi pada tahun 2017 Pola asuh makan yang baik yaitu dapat memenuhi asupan, frekuensi serta jenis makanan yang dapat mempengaruhi gizi seseorang, karena sesuai dengan kebutuhan dan pemilihan bahan makanan yang tepat akan mendapatkan status gizi yang baik juga. Apabila asupan makanan yang melebihi kapasitas dari kebutuhan tubuh akan menyebabkan berat bada meningkat dan dapat menyebabkan penyakit lainnya. Sebaliknya, asupan makan yang kurang dari yang kebutuhkan akan menyebabkan tubuh rentan terhadap penyakit dan berat badan $\operatorname{turun}(17)$.

Berdasarkan penelitian, peneliti menyimpulkan bahwa pola asuh makan pada anak sudah baik, didukung dengan sikap positif tentang makanan yang dikatakan ibu kepada anak, mendorong anak untuk selalu ingin mencoba masakan baru, dan tetap meminta anak untuk makan apa yang ibu masak dirumah. Pola asuh makan pada anak usia prasekolah sangat penting dalam proses tumbuh kembang, termasuk dalam pemenuhan sayuran dan buahan. Makanan dengan zat gizi memiliki hubungannya dengan kesehatan, kecerdasan dan tumbuh kembang anak.

Tabel 5. Identifikasi Praktek Pemberian Makan dalam Pemenuhan Konsumsi Sayur dan Buah pada Anak Prasekolah

\begin{tabular}{|c|c|c|c|c|}
\hline \multirow{2}{*}{ Praktik Pemberian Makan } & \multicolumn{3}{|c|}{ Ya } & Tidak \\
\hline & $\mathrm{N}$ & $\%$ & $\mathrm{~N}$ & $\%$ \\
\hline $\begin{array}{l}\text { Tidak memaksa anak untuk } \\
\text { menghabiskan makanan yang disiapkan }\end{array}$ & 135 & 70.3 & 57 & 29.7 \\
\hline $\begin{array}{l}\text { Mengajak anak makan sambil bermain } \\
\text { dan berjalan diluar rumah }\end{array}$ & 104 & 54.2 & 88 & 45.8 \\
\hline $\begin{array}{l}\text { Mendampingi dan mengawasi anak } \\
\text { ketika makan }\end{array}$ & 180 & 93.8 & 12 & 6.3 \\
\hline Jika disuapkan sayur lebih banyak habis & 144 & 75.0 & 48 & $25 \cdot 5$ \\
\hline $\begin{array}{l}\text { Jika makan sendiri sayur lebih banyak } \\
\text { habis }\end{array}$ & 133 & 69.3 & 59 & 30.7 \\
\hline $\begin{array}{l}\text { Jika makan disuapi pembantu, maka } \\
\text { anak akan menghabiskan sayur lebih } \\
\text { banyak }\end{array}$ & 155 & 80.7 & 37 & 19.3 \\
\hline
\end{tabular}

Hasil penelitian didapatkan bahwa dari 192 responden pada penelitian ini didapatkan sebagian besar responden benar untuk tidak memaksa anak untuk menghabiskan makanan yang disiapkan sebanyak 135 orang (70.3\%), sebagian besar benar untuk mengajak anak makan sambil bermain dan berjalan diluar rumah sebanyak 104 orang (54.2\%), sebagian besar mendampingi dan mengawasi anak ketika makan sebanyak 180 orang (93.8\%), sebagian besar benar Jika disuapkan oleh asisten rumah tangga maka anak akan menghabiskan sayur lebih banyak sebanyak 144 orang $(75,0 \%)$.

Praktik pemberian makan yaitu dilihat dari peran ibu dalam pemenuhan pemberian makan pada anak dimulai dari menyiapkan makanan hingga menyajikan makanan. Pengawasan ibu terhadap makanan habis dikonsumsi apabila anak makan sendiri, disuapin ibu dan disuapin oleh pembantu.

Penelitian ini sejalan dengan penelitian Livia pada tahun 2016 yang menyebutkan bahwa praktik ibu dalam pemberian makan pada anak adalah tindakan yang dapat dilihat atau diawasi. Komsumsi buah dan sayur yang diberikan kepada anak dapat dilihat dari cara pengolalahan dan cara memberikan kepada anak. Hasil penelitian ini didapatkan bahwa sebagian besar responden masih kurang dalam 
praktek pemberian makan pada anak. Tindakan ibu dalam menyediakan sayuran dan buahan atau tidak menyediakan akan mempengaruh terhadap kebiasaan anak mengkonsumsi sayuran dan buahan.

Berdasarkan penelitian, peneliti menyimpulkan bahwa praktek pemberian makan pada anak mempunyai peranan yang sangat penting dalam asupan nutrisi bagi anak. Praktek pemberian makan merupakan perilaku orang tua dalam memenuhi kebutuhan energi dan zat gizi pada anak, pemberian makan akan mempengaruhi asupan makan pada anak. Praktek pemberian makan pada anak juga harus diperhatikan ibu dalam metode pemberian makan, memperhatikan nafsu makan anak, situasi pemberian makan, waktu pemberian makan yang tepat, perhatian dan perlindungan selama anak makan.

Tabel 6. Identifikasi Penyediaan Makanan dalam Pemenuhan Konsumsi Sayur dan Buah pada Anak Prasekolah

\begin{tabular}{lcccccc}
\hline \multicolumn{1}{c}{ Penyediaan Makanan } & \multicolumn{2}{c}{ Selalu } & \multicolumn{2}{c}{ Kadang-Kadang } & \multicolumn{2}{c}{ Tidak Pernah } \\
\cline { 2 - 7 } & $\mathrm{N}$ & $\%$ & $\mathrm{~N}$ & $\%$ & $\mathrm{~N}$ & $\%$ \\
\hline $\begin{array}{l}\text { Sayur dan buah selalu tersedia setiap } \\
\text { hari dirumah }\end{array}$ & 132 & 68.8 & 59 & 30.7 & 1 & 5 \\
\hline $\begin{array}{l}\text { Sayur dan buah bervariasi setiap } \\
\text { harinya }\end{array}$ & 102 & 53.1 & 87 & 45.3 & 3 & 1.6 \\
\hline $\begin{array}{l}\text { Setiap jam sayur dalam bentuk kuah } \\
\text { dan lalapan }\end{array}$ & 108 & 56.3 & 67 & 34.9 & 17 & 8.9 \\
\hline $\begin{array}{l}\text { Sayur dan buah didapatkan dari hasil } \\
\text { kebun }\end{array}$ & 18 & 9.4 & 54 & 28.1 & 120 & 62.5 \\
\hline Sayur ditanam dilingkungan rumah & 16 & 8.3 & 34 & 17.7 & 142 & 74.0 \\
\hline Menanam buah diperkarangan rumah & 74 & 38.5 & 41 & 21.4 & 77 & 40.1 \\
\hline $\begin{array}{l}\text { Selalu membeli sayur dan buah yang } \\
\text { tidak cepat busuk }\end{array}$ & 62 & 32.3 & 69 & 35.9 & 61 & 31.8 \\
\hline $\begin{array}{l}\text { Sayur dan buah tersedia jika pada } \\
\text { musimnya saja }\end{array}$ & 152 & 79.2 & 29 & 15.1 & 11 & 5.7 \\
\hline $\begin{array}{l}\text { Hanya buah yang berwarna merah } \\
\text { yang banyak manfaatnya }\end{array}$ & 127 & 66.1 & 44 & 22.9 & 21 & 10.9 \\
\hline $\begin{array}{l}\text { Setiap makan sayur nasi menjadi } \\
\text { lembek dan tidak enak }\end{array}$ & 168 & 87.5 & 17 & 8.9 & 7 & 3.6 \\
\hline $\begin{array}{l}\text { Sayur yang berwarna hijau banyak } \\
\text { manfaatnya }\end{array}$ & 96 & 50.0 & 51 & 26.6 & 45 & 23.4 \\
\hline
\end{tabular}

Hasil penelitian didapatkan bahwa dari 192 responden pada penelitian ini didapatkan sebagian besar responden selalu tersedia sayur dan buah setiap hari dirumah sebanyak 132 orang (68,8\%), sebagian besar selalu Sayur dan buah bervariasi setiap harinya sebanyak 102 orang (53,1\%), sebagian besar selalu Setiap jam sayur dalam bentuk kuah dan lalapan sebanyak 108 orang (56,3\%), sebagian besar tidak pernah Sayur dan buah didapatkan dari hasil kebun sebanyak 120 orang (62,5\%), sebagian besar tidak pernah Sayur ditanam dilingkungan rumah sebanyak 142 orang $(74,0 \%)$, sebagian besar kadang-kadang membeli sayur dan buah yang tidak cepat busuk sebanyak 69 orang (35,9\%), sebagian besar selalu Sayur dan buah tersedia jika pada musimnya saja sebanyak 152 orang $(79,2 \%)$, sebagian besar selalu Hanya buah yang berwarna merah yang banyak manfaatnya sebanyak 127 orang $(66,1 \%)$, sebagian besar selalu Setiap makan sayur nasi menjadi lembek dan tidak enak sebanyak 168 orang $(87,5 \%)$, dan sebagian besar selalu Sayur yang berwarna hijau banyak manfaatnya sebanyak 96 orang $(50,0 \%)$.

Penyediaan makanan yang dimaksud yaitu ada atau tidaknya ketersediaan buah dan sayur dirumah dan disekitar rumah responden. Ketersediaan buah dan sayur terutama dirumah memiliki hubungan yang bermakna dengan tingkat konsumsi buah dan sayur pada anak. Apabila ketersediaan buah dan sayur dirumah kurang, maka akan membuat referensi dari anak untuk mengetahui sayu dan buahan menjadi kurang (7). 
Berdasarkan hasil penelitian dari Airin pada tahun 2012 bertolak belakang dengan penelitian ini karena penyediaan sayur dan buah dirumah setiap harinya juga kurang baik dilihat dari jumlah ibu sebanyak 38,1\%. Menurut Wirakusumah pada tahun 2013 mengatakan bahwa konsumsi sayur setiap hari sangatlah penting, karena sayur mengandung banyak vitamin, mineral dan serat yang merupakan unsur penting untuk tubuh dalam proses metabolisme.

Hasil penelitian Bordheauduij pada tahun 2008 didapatkan bahwa terdapat hubungan yang signifikan antara ketersediaan buahan dan sayuran dirumah dengan tingkat konsumsi buah dan sayur pada anak. Semakin tinggi ketersediaan buah dan sayur maka semakin tinggi pula konsumsi sayur dan buah pada anak(18). Penelitian Sandvik pada tahun 2005 mendapatkan bahwa sebagian besar anak usia sekolah di negara eropa memiliki ketersediaan buah dan sayur yang cukup dirumah setiap hari. Tetapi tidak didukung dengan ketersediaan buah dan sayur disekitar rumah dan sekolahnya.

Hasil Penelitian Brug pada tahun 2005 mengatakanbahwa ketersediaan buahan dan sayuran kurang maka kepada anak juga akan terbatas sehingga akan mengurangi kesukaan anak terhadap buah dan sayur. Ketersediaan buahan dan sayuran dirumah akan memperngaruhi besar dengan komsumsi pada anak pra sekolah (19).

Berdasarkan Penelitian, peneliti menyimpulkan bahwa ketersediaan buahan dan sayuran adalah ada atau tidaknya buahan dan sayuran dirumah dan disekitar lingkungan responden. Ketersediaan buah dan sayur dirumah dan disekitar rumah responden meningkatkan jumlah konsumsi sayur dan buah bagi anak sehingga mampu mencapai kebutuhan nutrisi yang dibutuhkan anak.

Tabel 7. Distribusi Frekuensi Responden Berdasarkan Identifikasi Cara Pengolahan Makan dalam Pemenuhan Konsumsi Sayur dan Buah Pada Anak Prasekolah di Wilayah Kerja Puskesmas Payung Sekaki

\begin{tabular}{lcccc}
\hline \multirow{2}{*}{ Cara Pengolahan Makanan } & $\mathrm{N}$ & $\%$ & $\mathrm{~N}$ & $\%$ \\
\cline { 2 - 5 } $\begin{array}{l}\text { Mengolah makanan untuk } \\
\text { anak menggunakan bahan } \\
\text { yang masih segar dan } \\
\text { berkualitas baik }\end{array}$ & 187 & 97.4 & 5 & 2.6 \\
\hline $\begin{array}{l}\text { Mengolah makanan untuk } \\
\text { anak menggunakan bumbu } \\
\text { yang beraroma tajam }\end{array}$ & 32 & 16.7 & 160 & 83.3 \\
\hline $\begin{array}{l}\text { Mengolah makanan sayur } \\
\text { dan buah langsung diberikan } \\
\text { kepada anak tanpa dicuci } \\
\text { terlebih dahulu }\end{array}$ & 22 & 11.5 & 170 & 88.5 \\
\hline
\end{tabular}

Hasil penelitian didapatkan bahwa dari 192 responden didapatkan sebagian besar responden benar dalam Mengolah makanan untuk anak menggunakan bahan yang masih segar dan berkualitas baik sebanyak 187 orang (97,4\%), sebagian besar ibu Mengolah makanan untuk anak menggunakan bumbu yang beraroma tajam sebanyak 160 orang (83,3\%), dan sebagian besar responden tidak Mengolah makanan sayur dan buah langsung diberikan kepada anak tanpa dicuci terlebih dahulu sebanyak 170 orang $(88,5 \%)$.

Pengolahan makanan merupakan proses perubahan dari bentuk bahan mentah menjadi makanan yang siap di komsumsi dengan memperhatikan aturan cara pengolahan makanan yangbenar. Pengolahan buah-buahan dapat dilakukan dengan berbagai proses diantaranya adalah pengeringan, perebusan, penggulaan, penggaraman, penggorengan, fermentasi, pengalengan. Teknologi pengolahan dan peralatan yang digunakan pun sederhana sehingga dapat diterapkan di rumah(20).

Hasil penelitian Diah pada tahun 2015 menyatakan bahwa rata-rata responden mengolah sayuran dengan direbus atau ditumis, sedangkan buah yang disajikan dengan cara dipotong kecil dan langsung disantap serta disajikan dengan cara diblender dijadikan minuman yang segar(21). Sejalan dengan penelitian Livia pada 
tahun 2016 mengatakan bahwa sebagian besar responden masih kurang dalam pengolahan sayuran yaitu memotong dulu kemudian mencuci, namun cara yang seharusnya dilakukan yaitu mencucinya dulu baru kemudian memotongnya, dan masaknya jangan terlalu lama krena akan mempengaruhi kandungan gizi yang ada disayuran. Tindakan ini dipengaruhi oleh pengetahuan ibu mengenai pengolahan sayur.

Hasil penelitian Airin pada tahun 2012 didapatkan bahwa sikap yang kurang baik oleh ibu untuk proses pengolahan sayuran sebanyak $77,8 \%$, yaiu ibu tidak setuju sayuran dicuci dahulu baru dipotong-potong. Sedangkan ibu yang menyetujui masak sayuran harus matang sebanyak 52,4\%. Sejalan dengan penelitian Agnes pada tahun 2015 didapatkan untuk medapatkan hidangan sayuran yang bergizi dilihat dari penanganan yang tepat dimulai dari pemilihan sampai pengolahan terakhir sebelum dihidangkan(22).

Berdasarkan penelitian, peneliti menyimpulkan bahwa cara pengolahan makanan yang baik harus melalui prinsip hygiene dari pemilihan bahan makanan sampai dengan hasil penyajian makanan. Pengolahan makanan yang tepat tidak merusak nilai gizi yang terdapat dalam makanan tersebut sehingga nutrisi yang masuk ketubuh anak dapat terpenuhi maksimal.

\section{KESIMPULAN DAN SARAN}

Berdasarkan hasil penelitian yang telah dilakukan peneliti mengenai gambaran upaya ibu dalam pemenuhan konsumsi sayur dan buah pada anak prasekolah di Wilayah Kerja Puskesmas Payung Sekaki yang telah dilakukan pada tanggal 13 Mei 2019 dengan 192 responden diperoleh hasil dalam penelitian ini didapatkan sebagian besar responden Ibu pada usia dewasa awal dalam rentang usia 26-35 tahun sebanyak 111 orang $(57,8 \%)$, untuk responden anak sebagian besar responden berusia 6 tahun sebanyak 57 orang (29,7\%), Sebagian besar responden berpendidikan SMA sebanyak 88 orang (45,8\%). Hasil variabel penelitian dari 192 responden pada penelitian ini didapatkan sebagian besar kebiasaan makan cukup yaitu 169 orang $(88,0 \%)$, selain itu untuk pola asuh makan didapatkan sebagian besar pola asuh yang baik yaitu sebanyak 191 orang (99,5\%), untuk praktek pemberian makan sebagian besar responden benar yaitu sebanyak 97 orang $(50,5 \%)$, untuk penyediaan makan didapatkan responden baik yaitu sebanyak 190 orang $(99,0 \%)$, dan untuk cara pengolahan makan sebagian besar benar yaitu 145 orang $(75,5 \%)$.

\section{REFERENSI :}

1. Almatsier.S, Soetardjo.S, S. Gizi Seimbang Dalam Daur Kehidupan. (Almatsier.S, Ed.) (1st ed.). PT Gramedia Pustaka Utama. 2011.

2. Santoso, S. Ranti, A. Kesehatan dan Gizi. Jakarta. Rineka Cipta. 2014.

3. Sediaoetama.A.D. Ilmu Gizi (2nd ed.). PT Dian Rakyat. 2009.

4. Hasdianah.H.R, Sitiyo.S, P. Gizi, Pemanfaatan Gizi, Diet dan Obesitas (1st ed.). Nuha Medika. 2014.

5. Hurlock, E. B. Psikologi Perkembangan Suatu Pendekatan Sepanjang Rentang Kehidupan (Alih Bahasa Istiwidayanti dkk. Edisi Kelima. Jakarta. Erlangga. 2010.

6. Elizabeth., Shim, Mi-suk., Caplovitz, Allison. Linking Obesity and Activity Level With Children's Television and Video Game Use. Journal of Adolescene 27. 2010.

7. Tejasari. Nilai Gizi Pangan (1st ed.). Yogyakarta. Graha Ilmu. 2005.

8. Fitriani, F. Gambaran Penyebab Kesulitan Makan Pada Anak Prasekolah Usia 35 tahun Di Perumahan Top Amin Mulya Jakabaring Palembang Tahun 2009. 2009.

9. Worthington. 2000. Nutrition Troughout The Life Cycle. The MasGraw-Hill International Edition: USA

10. Rini. 2009. Panduan ilmu gizi pada anak. Yogyakarta

11. Windi. 2016. Food Combining. Jakarta : EGC

12. Khomsan. 2010. Pangan dan gizi untuk kesehatan. Jakarta: PT. Raja Frafindo Persada.

13. Aritonang. Model Multilevel Pertumbuhan Anak Usia 0-24 bulan dan variabel yang mempengaruhinya. Jurnal Penelitian dan Evaluasi Pendidikan. Yogyakarta. Politeknik Kesehatan Kemenkes Yogyakarta. 2011:130-142. 
14. Rona, S,M.,P. Hubungan pola makan dengan timbulnya gastritis pada pasien di universitas muhamadiyah malang medical center (UMC). Keperawatan. 2017.

15. Anisa, R. Kesejahteraan Siswa pada Keluarga Pra Sejahtera. Skripsi. Universitas Muhammadiyah Surakarta. Fakultas Psikologi. 2014.

16. Vereecken. Konsumsi Sayur Dan Buah Di Masyarakat Dalam Konteks Pemenuhan Gizi Seimbang. Jurnal Kependudukan Indonesia. 2004.

17. Dwi. Kebiasaan Makan Dan Gangguan Pola Makan Serta Pengaruhnya Terhadap Status Gizi Remaja. Jurnal Publikasi Pendidika. 2017;6(1).

18. Bourdeaudhuij, et al. Personal, social and environmental predictors of daily fruit and vegetable intake in 11 years old children in nine European countries. European journal of clinical nutritiron. 2008;6:834-841.

19. Brug, J, Tak, N,I, te Velde, S,J,, Bere, E., dan de Bourdeaudhuij, I. Taste Preferences, Liking and Other Factors Related to Fruit and Vegetable Intakes among Schoolchildren: result from Observational Studies. British Journal of Fruit. 2008;99. Suppl. 1 S7-S14.

20. BPTP. 2007. Balai penyuluhan pertahian. Jakarta: EGC

21. Diah, A.K., \& Yuni, A. Hubungan Pengetahuan Remaja Putri Usia 11-14 Tahun Dengan Tingkat Kecemasan Dalam Mengahadapi gastritis Di Mts Safinatul Huda Sowan Kidul Jepara. Jurnal Kesehatan dan Keperawatan. 2015;6(1):68-85.

22. Agnes. Penyakit Akibat Lalai Mengkonsumsi Buah Dan Sayur Serta Solusi Penyembuhannya. Jurnal Teknologi dan Industri Pangan. Jakarta Rineka Cipta.2010. 2015. 